\title{
ANALISIS EFEKTIVITAS PESAN FILM ANIMASI 3D BAHAYA ROKOK TERHADAP PEROKOK AKTIF REMAJA DAN DEWASA
}

\author{
Silvia Anggelina ${ }^{1}$, Anggy Trisnadoli ${ }^{2}$ \\ 1,2Jurusan Teknologi Informasi, Politeknik Caltex Riau \\ silvia16ti@mahasiswa.pcr.ac.id ${ }^{1}$, anggy@pcr.ac.id ${ }^{2}$
}

\begin{abstract}
Abstrak
Konsumsi rokok adalah penyebab global yang utama dari kematian yang masih dapat dicegah. Upaya pemerintah dalam mengendalikan dampak negatif konsumsi rokok sudah dilakukan dengan Peringatan Kesehatan Bergambar atau Pictorial Health Warning (PHW) pada bungkus rokok yang dipasarkan sejak tahun 2014 namun perlu adanya alternatif lain dalam mendukung kegiatan pemerintah tersebut. Salah satu alternatif yang diangkat pada penelitian ini adalah menyalurkan pesan bahaya merokok lewat sebuah media audio visual yaitu film animasi 3D berjudul Bahaya Rokok. Penelitian ini berfokus pada efektivitas pesan pada film dan efektivitas diukur berdasarkan tingkat pengetahuan akan bahaya merokok, serta tingkat keinginan perokok untuk berhenti merokok setelah menonton film. Penelitian menggunakan metode deskriptif kuantitatif. Dari pengujian yang telah dilakukan, didapatkan hasil bahwa film animasi 3D berhasil dibuat sebagai alternatif media sosialisasi kesehatan tentang bahaya merokok bagi perokok aktif remaja dan dewasa, serta dapat menyampaikan pesan bahaya merokok secara efektif bagi sebagian besar responden dan dominan lebih berpengaruh kepada perokok aktif remaja. Pesan bahaya merokok dapat disampaikan secara efektif dibuktikan dengan adanya peningkatan pengetahuan dan niat berhenti merokok yang timbul sebesar $30 \%$ pada responden penelitian setelah menonton film animasi 3D.
\end{abstract}

Kata Kunci: efektivitas pesan, film animasi 3D, rokok

\begin{abstract}
Cigarette consumption is the predominant global cause of death that can still prevent. The government efforts in restraining the negative impact of cigarette consumption have done with Pictorial Health Warning (PHW) On cigarette packaging that marketed since 2014 and yet there should have been an alternative in supporting the government. One of the alternatives that appointed in this research is transmitting a message about the dangers of smoking through audiovisual media, the animated 3D film called Danger of Smoking. This research is focusing on the effectiveness of the film. The effectiveness measured based on the level of knowledge of the danger of smoking, and the intention level of smokers to quit smoking after watching the film. The research used a descriptive quantitative method. The research used a descriptive quantitative method. From the testing that has done, the results showed that the animated $3 D$ film successfully made as an alternative media of health socialization regarding the danger of smoking for teenage and adult active smokers, and can deliver the message of the danger of smoking effectively for the majority of respondents and dominantly more affected for teenage active smokers. The danger of smoking messages can be delivered effectively proven by increasing knowledge and arising of intention to quit smoking by $30 \%$ on research respondents after watching the animated 3D film.
\end{abstract}

Keywords: 3D animated film, cigarettes, message's effectiveness 


\section{PENDAHULUAN}

Rokok mengandung lebih dari 4000 bahan kimia. Setidaknya, 60 dari bahan kimia tersebut mampu menyebabkan kanker. Bahan-bahan berbahaya pada sebatang rokok, di antaranya Karbon monoksida, Tar, Gas oksidan dan Nikotin. Dan beberapa gangguan kesehatan akibat merokok adalah kanker paru, gangguan pada mulut dan tenggorokan, gangguan psikologis, gangguan kardiovaskular, kulit serta membahayakan orang lain seperti perokok pasif dan gangguan kehamilan.

Konsumsi rokok adalah penyebab global yang utama dari kematian yang masih dapat dicegah. World Health Organization atau WHO menyebutkan kematian akibat rokok bisa mencapai lebih dari 7 juta jiwa per tahun. Menurut Riset Kesehatan Dasar (Riskesdas) tahun 2018, prevalensi (\%) perokok pada penduduk Indonesia usia $\geq 15$ tahun adalah sebesar 62.9 \% pada Laki-laki, $4.8 \%$ pada Perempuan dan total keduanya adalah $33.8 \%$. Dapat disimpulkan bahwa angka konsumsi rokok tersebut masih sangat tinggi dan kontradiksi dengan upaya pemerintah yang telah menggunakan Peringatan Kesehatan Bergambar atau Pictorial Health Warning (PHW) pada bungkus rokok yang dipasarkan sejak pertengahan tahun 2014 . Hampir $60 \%$ pembeli rokok memilih untuk membeli rokok yang kemasannya tidak disertai oleh PHW atau yang paling tidak menakutkan yang artinya penggunaan gambar penyakit yang menyeramkan memberikan efek bagi perokok. Mengingat berbagai dampak negatif akibat rokok bagi kesehatan manusia, maka perlu adanya alternatif sosialisasi pesan bahaya merokok. Namun sangat disayangkan bila upaya pemerintah tidak didukung dengan alternatif lain dalam mengkampanyekan bahaya merokok itu sendiri selain melalui bungkus rokok yang dipasarkan, salah satu alternatif lain tersebut yaitu melalui media audio visual.

Putri (2016) menjelaskan film merupakan bagian dari media audio visual gerak. Penelitian yang dilakukan oleh Saleh dkk. (2016) menyebutkan paparan film yang memberikan konten rokok merupakan faktor resiko yang memberikan efek niat merokok pada penonton khususnya remaja. Selain efek negatif, film juga dapat menjadi peluang baik untuk mengenalkan nilai positif serta menjadi media yang efektif untuk mensosialisasikan tentang bahaya rokok bagi remaja ataupun perokok. Dari penelitian sebelumnya ini, masih belum dianalisis lebih khusus untuk film yang berisi konten bahaya merokok dan reaksinya terhadap perokok, penelitian Saleh dkk. (2016) masih membahas konten-konten film yang berisikan unsur merokok dan pengaruhnya kepada penonton. Oleh karena itu penelitian ini akan berfokus pada film dengan konten khusus tentang bahaya merokok dengan target penonton langsung kepada perokok aktif remaja dan dewasa. Untuk penjelasan materi mengenai bahaya rokok dan proses negatif yang ditimbulkan oleh rokok dapat divisualisasikan dengan lebih baik dan menarik dengan teknologi animasi. Animasi merupakan salah satu bentuk visual bergerak yang dapat dimanfaatkan untuk menjelaskan materi pelajaran yang sulit disampaikan secara konvensional.

Penjelasan-penjelasan di atas menjadi dasar dalam penelitian ini yakni membangun sebuah film animasi 3D guna menyampaikan pesan tentang bahaya merokok kepada perokok aktif remaja dan dewasa. Penelitian yang dilakukan oleh Suryani (2014) dan 
Nuswantari (2014) menyatakan bahwa film animasi mampu menyampaikan pesan moral yang ingin disampaikan dengan kombinasi hal yang menyenangkan. Hamdan (2015) menyebutkan bahwa kebanyakan orang Indonesia malas membaca dan pada pencantuman tulisan peringatan bahaya merokok perlu bersifat persuasif dan dramatis agar dapat menggugah pembaca untuk menilai dan menentukan tindakan. Dalam penelitian yang dilakukan oleh Kadar dkk (2017), ada hubungan antara pengetahuan bahaya rokok dengan perilaku merokok tersebut sementara Rhyandina dkk. (2017) dalam penelitiannya menyimpulkan hasil yang kurang memuaskan karena masih ada sebagian yang acuh dan sebagian ada yang berhasil mengubah pandangan tentang bahaya uap dari rokok elektrik. Pemaparan-pemaparan penelitian terdahulu tersebut merupakan dasar dirancangnya penelitian ini yang mengangkat tema kesehatan khususnya bahaya merokok.

Pada penelitian ini, terdapat beberapa hal yang diperhatikan dalam pembuatan film promosi kesehatan anti merokok berdasarkan penelitian Saleh dkk. (2016) yakni yang pertama dilihat dari tujuan film, yaitu sebagai sarana informasi dapat menyampaikan informasi yang baik dan benar, sesuai dengan kenyataan, tidak direkayasa, masuk akal atau dibesar-besarkan. Selanjutnya ialah konten atau isi pesan, yaitu memperhatikan kemudahan penonton menerima pesan yang disampaikan, kejelasan pesan yang disampaikan, pesan moral yang terkandung di dalamnya, fungsi pesan untuk mentransfer pengetahuan dan pesan yang disampaikan dapat mengembangkan sikap. Terakhir dilihat dari sisi penokohan. Pemilihan tokoh yang dipilih harus akrab dan sesuai dengan karakter penonton. Tokoh utama harus digambarkan memiliki karakter yang baik sehingga akan mempengaruhi niat remaja untuk berbuat hal yang sama dengan tokoh yang dilihatnya. Ketiga poin utama ini menjadi dasar penelitian dalam membangun film animasi 3D bahaya merokok untuk mencapai tujuan yang diharapkan dalam penyampaian pesan bahaya merokok.

Pada akhirnya penelitian ini akan menganalisis efektivitas pesan bahaya merokok apakah dapat memberikan pengetahuan tentang bahaya rokok serta menimbulkan keinginan untuk berhenti merokok. Harapan dari penelitian ini adalah dapat menemukan kesimpulan efektivitas pesan bahaya merokok yang disampaikan lewat film animasi 3D terhadap perokok aktif remaja dan dewasa sehingga dapat dijadikan alternatif media sosialisasi tentang bahaya merokok.

\section{METODE PENELITIAN}

Untuk mencapai tujuan pada penelitian ini, telah dilakukan beberapa tahapan. Penelitian ini dimulai dari proses brainstorming mengenai permasalahan konsumsi rokok pada remaja dan dewasa berdasarkan berita, media ataupun artikel kesehatan yang ada. Kemudian dilanjutkan dengan survei kepada salah satu pihak dari Dinas Kesehatan Provinsi Riau mengenai respon terhadap ide pembuatan film animasi 3D untuk penyampaian pesan bahaya merokok. Selanjutnya dilakukan tahap pembuatan animasi berdasarkan tahapan pembuatan film animasi 3D. Setelah tahap pembuatan animasi selesai, dilakukan pengujian yang terbagi atas dua tahap diantaranya checklist kesesuaian film dan analisis efektivitas film. Terakhir adalah pembuatan laporan dari 
keseluruhan penelitian yang sudah dilakukan dari awal hingga akhir. Dimana proses metodologi penelitian dapat lebih jelas dilihat pada Gambar 1.

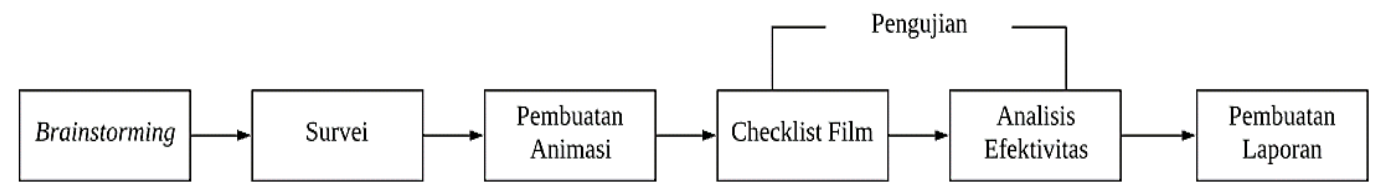

Gambar 1. Block diagram gambaran umum penelitian

[Sumber: Dokumentasi Penulis]

Pengujian checklist kesesuaian film dilakukan terhadap dokter dari Dinas Kesehatan Provinsi Riau sebagai sarana validasi kesesuaian konten pada film sebelum diujikan kepada penonton, karena film yang dibuat harus benar data dan sumber kesehatannya untuk dapat diyakini oleh penonton kedepan.

Pengujian kedua yaitu analisis efektivitas, yang menjadi inti dari ini. Penelitian ini diuji dengan penelitian deskriptif menggunakan metode pengambilan data kuantitatif melalui kuesioner. Populasi dalam penelitian ini adalah masyarakat umum di Kota Pekanbaru. Sampel dari penelitian ini adalah sebagian dari masyarakat di Kota Pekanbaru dengan kriteria : 1) Perokok aktif remaja usia 12-25 tahun, 2) Perokok aktif dewasa usia 26-45 tahun dengan jumlah sampel total 50 orang. Pengambilan sampel penelitian dilakukan dengan teknik non random sampling dengan cara purposive sampling yaitu pengambilan sampel berdasarkan tujuan tertentu yang pada kasus ini adalah orang-orang yang merokok dengan rentang usia 12-45 tahun.

Tahapan pengujian dimulai dengan memberikan sebuah kuesioner berisi pertanyaan terkait pengetahuan akan bahaya rokok terhadap responden sebelum menonton film. Pengisian kuesioner ditahap awal ini akan dijadikan perbandingan dengan nilai pengetahuan yang didapat setelah menonton film. Selanjutnya responden akan diberikan kesempatan untuk menonton film animasi 3D pesan bahaya merokok yang telah siap dibuat. Setelah selesai menonton, responden akan kembali diberikan kuesioner dan menjawab pertanyaan-pertanyaan yang ada pada kuesioner yang diberikan. Hal utama yang akan dikukur dari penyebaran kuesioner kedua ada 4 variabel yaitu 1) Knowledge Bahaya Rokok, 2) Perasaan setelah menonton, 3) Keinginan berhenti merokok, 4) Alasan tetap merokok. Hasil pengumpulan data kemudian akan dihitung persentasinya berdasarkan masing-masing variabel pertanyaan untuk kemudian dianalisis apakah film yang dihasilkan telah efektif dalam menyampaikan pesan bahaya merokok secara umum bagi perokok aktif remaja dan dewasa. Pengujian ini menghasilkan output yang menyatakan apakah film animasi 3D efektif dalam penyampaian pesan bahaya merokok kepada perokok aktif remaja dan dewasa atau tidak.

\section{HASIL DAN PEMBAHASAN}

\subsection{Pengembangan Produk Film Animasi 3D}

Pembuatan film animasi dilakukan sesuai tahapan produksi film animasi 3D. Produk film dimulai dari tahapan Pra-Produksi yang intinya adalah perancangan ide cerita dan 
memvisualisasikan jalan cerita tersebut kedalam bentuk storyboard. Kemudian dilakukan tahap Produksi yang merupakan pengerjaan hal teknis seperti pembuatan karakter, penganimasian serta rendering. Setelah Produksi selesai tahap terakhir adalah Pasca Produksi yang meliputi compositing dan editing seluruh video hasil proses Produksi sebelumnya hingga menjadi film animasi 3D yang utuh. Cuplikan hasil film animasi 3D bahaya merokok ini dapat dilihat pada Gambar 2.
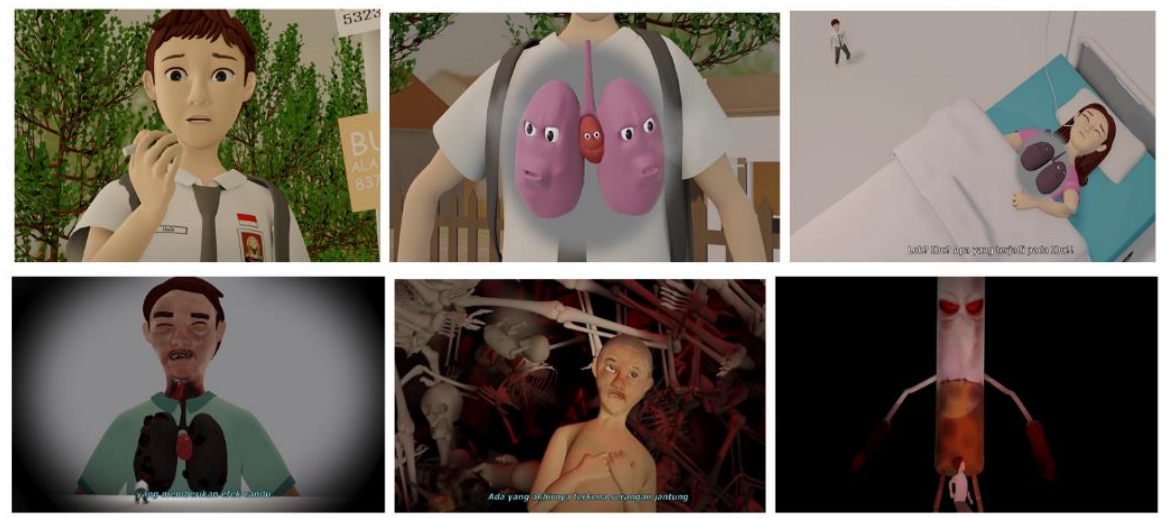

Gambar 2. Cuplikan film animasi 3D Bahaya Merokok

[Sumber: Dokumentasi Penulis]

\subsection{Analisis Efektivitas Pesan Bahaya Merokok Melalui Film}

Setelah produk film sudah selesai dibuat maka penelitian dilanjutkan dengan melakukan pengujian dari sisi kesesuaian film dan sisi efektivitas pesan bahaya merokok. Target penonton pada penelitian ini adalah perokok aktif remaja berusia 12-25 tahun dan dewasa berusia 26-45 tahun. Total responden pada penelitian ini berjumlah 50 orang. Pengujian ini terdiri dari dua cara diantaranya checklist kesesuaian film dan analisis efektivitas pesan bahaya merokok pada film.

Pengujian checklist kesesuaian film dilakukan terhadap dokter dari Dinas Kesehatan Provinsi Riau. Dari hasil pengujian checklist film yang telah dilakukan, diperoleh nilai $100 \%$ Ya pada delapan pernyataan yang telah disediakan terkait konten film bahaya merokok dan target penelitian yang ingin dicapai. Dengan mendapatkan nilai $100 \%$ pada pengujian checklist film ini, menjelaskan bahwa film animasi 3D bahaya merokok pada penelitian ini telah valid dari segi konten kesehatan bahaya merokok dan dapat ditonton oleh target penelitian ini yakni para perokok aktif remaja dan dewasa.

Tabel 1. Form Checklist Kesesuaian Film

\begin{tabular}{|c|l|c|c|}
\hline No & \multicolumn{1}{|c|}{ Pernyataan } & Ya & Tidak \\
\hline 1. & $\begin{array}{l}\text { Produk film menyampaikan informasi yang baik dan benar, sesuai } \\
\text { dengan kenyataan, tidak direkayasa, masuk akal atau dibesar- } \\
\text { besarkan. }\end{array}$ & $\sqrt{ }$ & $\sqrt{ }$ \\
\hline 2. & $\begin{array}{l}\text { Produk film dapat memberikan tontonan yang menghibur sekaligus } \\
\text { memberikan pesan positif yang baik. }\end{array}$ & $\sqrt{ }$ & \\
\hline 3. & $\begin{array}{l}\text { Konten atau isi pesan dalam produk film memperhatikan kemudahan } \\
\text { penonton menerima pesan yang disampaikan. }\end{array}$ & $\sqrt{ }$ & \\
\hline 4. & $\begin{array}{l}\text { Konten atau isi pesan dalam produk film secara jelas menyampaikan } \\
\text { pesan tentang sesuatu yang pantas dan tidak pantas ditiru. }\end{array}$ & \\
\hline
\end{tabular}




\begin{tabular}{|c|l|c|c|}
\hline No & \multicolumn{1}{|c|}{ Pernyataan } & Ya & Tidak \\
\hline 5. & $\begin{array}{l}\text { Konten atau isi pesan dalam produk film dapat mentransfer } \\
\text { pengetahuan yang menumbuhkan sikap mental untuk tidak merokok } \\
\text { atau menolak merokok. }\end{array}$ & $\sqrt{ }$ & \\
\hline 6. & $\begin{array}{l}\text { Produk film telah menggambarkan pesan bahaya merokok dengan } \\
\text { jelas dan baik. }\end{array}$ & $\sqrt{ }$ & $\sqrt{ }$ \\
\hline 7. & $\begin{array}{l}\text { Adanya relevansi tokoh di dalam film dengan target penelitian yaitu } \\
\text { perokok aktif remaja dan dewasa. }\end{array}$ & $\sqrt{ }$ & \\
\hline 8. & $\begin{array}{l}\text { Adanya sikap tokoh pada film yang menunjukkan aksi berani menolak } \\
\text { rokok. }\end{array}$ & & \\
\hline
\end{tabular}

Pengujian kedua yaitu analisis efektivitas, yang dilakukan dengan memberikan kesempatan bagi responden untuk mengisi kuesioner terkait pengetahuan akan bahaya merokok sebelum menonton lalu dilanjutkan dengan menonton film animasi dan terakhir mengisi kuesioner kembali untuk melihat apakah adanya manfaat yang didapatkan oleh responden.

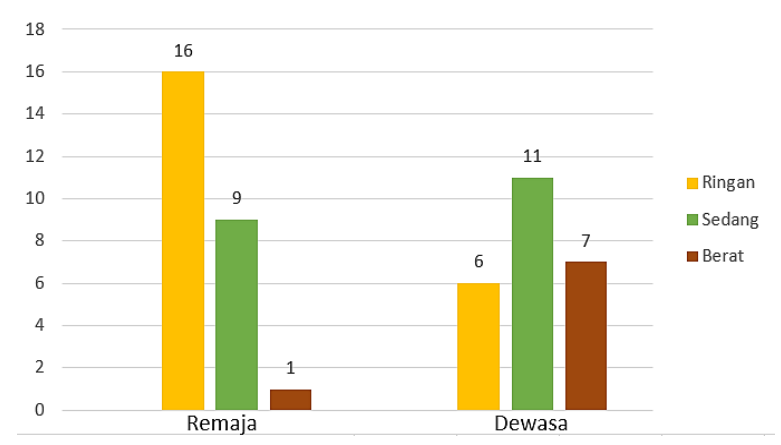

Gambar 3. Profil responden

[Sumber: Dokumentasi Penulis]

Sebagian besar responden pada penilitian ini adalah perokok aktif remaja dengan jumlah sebanyak 26 orang. Diikuti dengan responden perokok aktif dewasa dengan jumlah sebanyak 24 orang. Berdasarkan Gambar 3, ditunjukkan profil responden dalam penelitian ini yang dominan adalah perokok aktif remaja dengan tipe perokok aktif ringan menduduki posisi terbanyak.

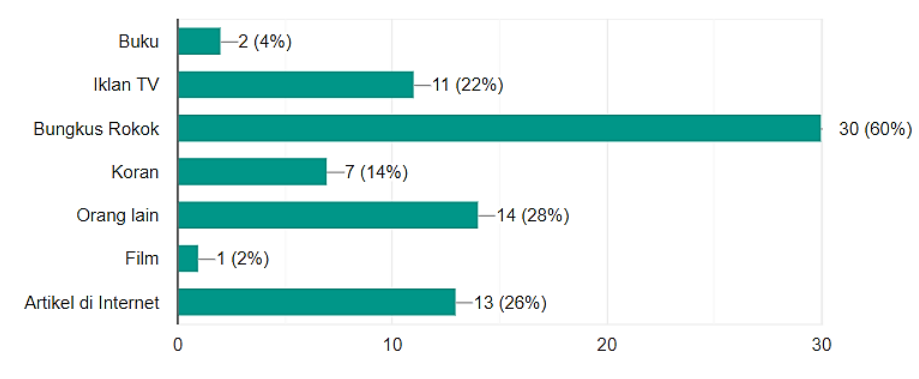

Gambar 4. Sumber pengetahuan responden [Sumber: Dokumentasi Penulis]

Selanjutnya dari pengujian ini juga ditemukan bahwa bungkus rokok merupakan sumber pengetahuan yang paling banyak dijumpai oleh responden, dimana disebutkan sebanyak 30 kali. Sumber pengetahuan responden ditunjukkan pada Gambar 4. 
Jika dilihat dari sumber pengetahuan bahaya merokok yang didapat oleh para responden selama ini, dominan mendapatkan pengetahuan dari bungkus rokok yaitu sebesar $60 \%$ dan paling kecil adalah film sebesar $1 \%$. Dari sumber pengetahuan tersebut, dapat disimpulkan bahwa peringatan dari bungkus rokok tersebut belum memberikan pengetahuan akan bahaya merokok yang baik karena persentase pengetahuan responden sebelum menonton lebih rendah dari pada setelah menonton film animasi bahaya merokok pada penelitian ini.

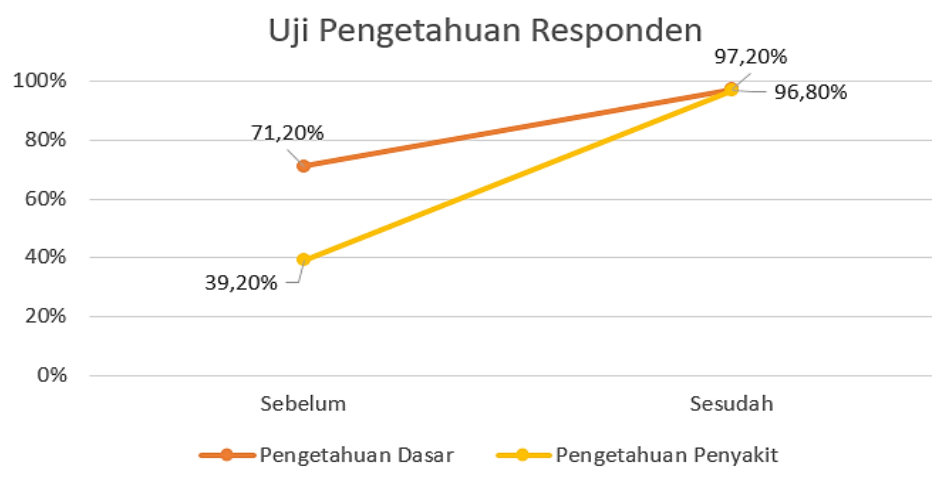

Gambar 5. Perbandingan pengetahuan responden [Sumber: Dokumentasi Penulis]

Dari pengujian ini, terlihat adanya peningkatan pengetahuan yang diperoleh oleh responden setelah menonton film animasi 3D bahaya merokok ini. Dari sisi pengetahuan dasar akan bahaya merokok, adanya peningkatan sebanyak $26 \%$ terhadap responden penelitian. Yang awalnya rata-rata pengetahuan dasar berada pada rata-rata persentase $71.20 \%$ benar, setelah menonton film pengetahuan meningkat menjadi $97.20 \%$ benar.Selain itu, jika dilihat dari sisi pengetahuan spesifik penyakit akibat bahaya merokok, adanya peningkatan sebanyak $57.60 \%$ terhadap responden penelitian. Awalnya rata-rata pengetahuan hanya sebesar $39.20 \%$ dan setelah menonton film animasi ini, meningkat menjadi $96.80 \%$ seperti yang ditunjukkan pada Gambar 5.

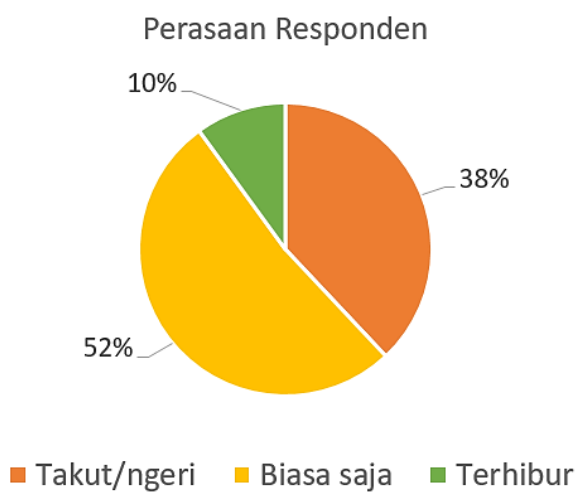

Gambar 6. Rekapitulasi perasaan responden saat menonton

[Sumber: Dokumentasi Penulis]

$82 \%$ responden menyatakan bahwa film ini memberikan peringatan bagi mereka untuk berhenti merokok dan $18 \%$ menyatakan film ini hanyalah suatu hiburan. Hal ini menunjukkan pesan bahaya merokok telah efektif disalurkan lewat film animasi 3D 
kepada para responden karena pesan memperingati untuk berhenti merokok dapat dicermati saat menonton dan memberikan perasaan takut/ngeri kepada sebagian besar responden yaitu sebesar $38 \%$ responden.

Saat dijabarkan lebih rinci, ditemukan bahwa responden yang paling banyak berpengaruh atau merasa diperingati adalah perokok remaja dengan kategori perokok ringan sementara untuk golongan perokok dewasa yang paling banyak adalah pada kategori perokok sedang. Selanjutnya dominan responden yang masih menganggap film ini hanyalah suatu hiburan didapati paling banyak berada pada responden perokok aktif dewasa. Dari pengujian ini dapat disimpulkan juga bahwa peringatan bahaya merokok yang disampaikan lewat film animasi 3D paling berpengaruh bagi perokok aktif remaja khususnya untuk tipe perokok kategori ringan dan kurang berpengaruh untuk perokok aktif dewasa, seperti yang ditunjukkan pada Gambar 7.

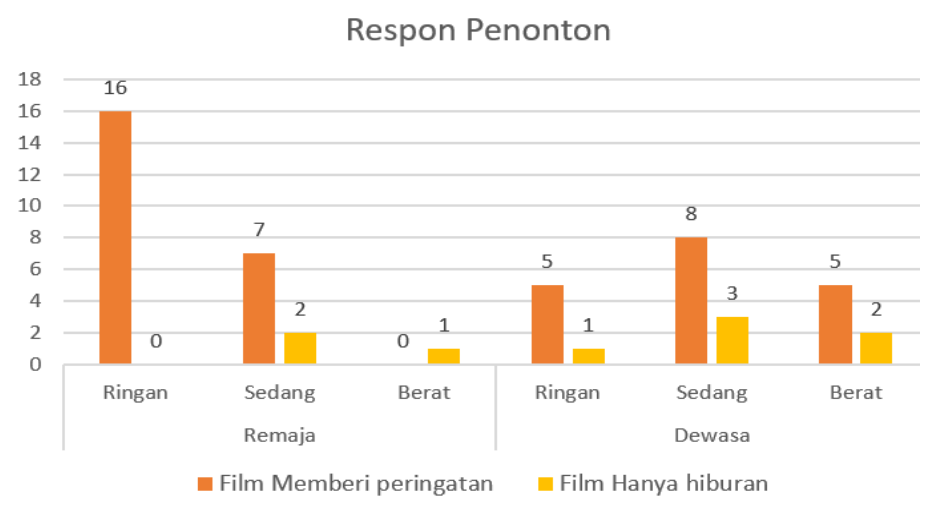

Gambar 7. Rekapitulasi pernyataan responden terkait film [Sumber: Dokumentasi Penulis]

Hal ini menunjukkan pesan bahaya merokok telah efektif disalurkan lewat film animasi 3D kepada para responden karena pesan memperingati untuk berhenti merokok dapat dicermati saat menonton dan cukup memberikan perasaan takut/ngeri kepada sebagian besar responden. Pertanyaan terakhir dari penelitian ini menyangkut keinginan responden untuk berhenti merokok seperti yang ditunjukkan pada Gambar 8.

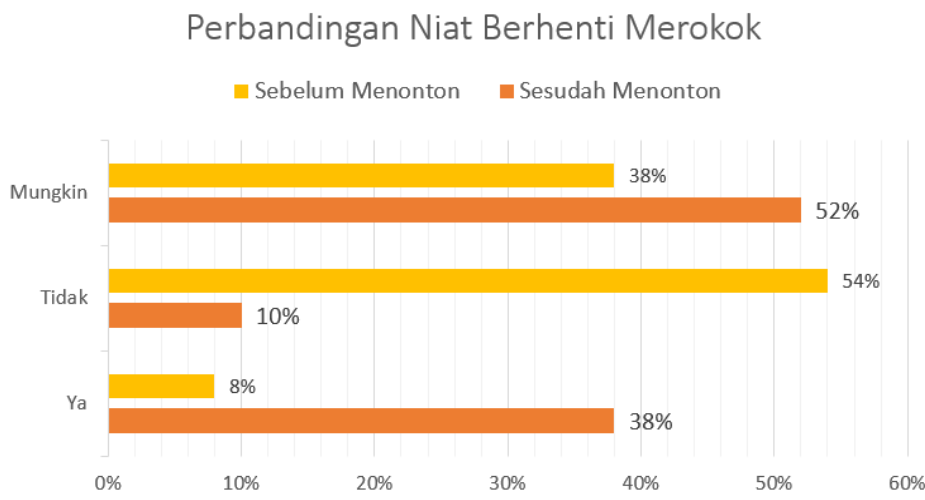

Gambar 8. Rekapitulasi keinginan berhenti merokok responden [Sumber: Dokumentasi Penulis] 
Berdasarkan data tersebut, dapat dilihat bahwa adanya penurunan persentase "Tidak" memiliki niat berhenti merokok sebesar $44 \%$ setelah menonton. Dari yang awalnya hanya $8 \%$ dari seluruh responden menyatakan "Ya" memiliki niat berhenti, naik sebesar $30 \%$ menjadi $38 \%$ responden memiliki niat untuk berhenti merokok. Hal ini menunjukkan bahwa film animasi 3D tentang bahaya merokok mampu memberikan pesan peringatan bagi sebagian responden untuk berhenti merokok.

Dari pengujian ini, didapatkan bahwa perokok aktif remaja kategori perokok ringan yang paling banyak memiliki niat untuk berhenti merokok ketimbang perokok aktif dewasa. Sementara pada golongan perokok aktif dewasa, kategori sedang yang paling banyak mendapatkan kesadaran untuk berhenti merokok setelah menonton film animasi 3D ini. Dari hal ini, kembali didapatkan simpulan bahwa film animasi 3D pada penelitian ini paling berpengaruh bagi perokok aktif remaja.

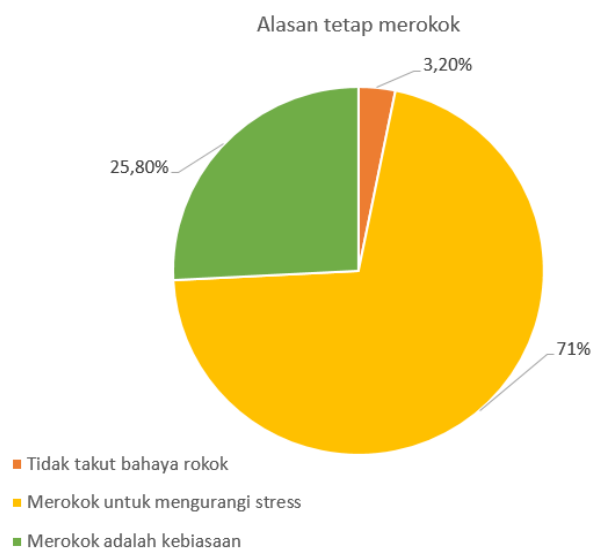

Gambar 9. Rekapitulasi alasan tetap merokok responden

[Sumber: Dokumentasi Penulis]

Saat ditelusuri alasan mengapa beberapa responden masih tidak bisa meninggalkan rokok, ternyata sebagian besar alasan responden tidak bisa meninggalkan rokok adalah untuk mengurangi stress. Seperti yang diketahui salah satu efek yang ditimbulkan oleh zat nikotin pada rokok adalah memberikan perasaan rileks pada perokok aktif sehingga perokok merasa stress pada diri berkurang dan menjadi faktor pendorong para responden untuk tetap merokok. Maka berdasarkan pengujian-pengujian yang telah dilakukan ini, didapati hasil yang menyimpulkan bahwa pesan bahaya merokok yang disampaikan lewat film animasi 3D dapat efektif disampaikan kepada sebagian besar responden.

\section{KESIMPULAN}

Adapun kesimpulan yang diperoleh dari penelitian ini adalah Film animasi 3D berhasil dibuat sebagai alternatif media sosialisasi kesehatan tentang bahaya merokok bagi perokok aktif remaja dan dewasa serta dapat menyampaikan pesan bahaya merokok secara efektif bagi sebagian besar responden dan dominan lebih berpengaruh kepada perokok aktif remaja. Film berhasil dibuat berdasarkan hasil pengujian Checklist kesesuaian film yang divalidasi oleh Dokter dari Dinas Kesehatan Provinsi Riau dan Pesan bahaya merokok dapat disampaikan secara efektif dibuktikan dengan adanya 
peningkatan pengetahuan pada responden setelah menonton film animasi 3D. Film animasi 3D pesan bahaya merokok pada penelitian dapat menyampaikan peringatan pesan bahaya merokok karena adanya peningkatan niat berhenti merokok yang timbul sebesar 30\% kepada responden penelitian.

Untuk pengembangan kedepannya, terdapat beberapa saran seperti memperhalus pergerakan animasi agar lebih nyaman untuk ditonton, mempersingkat durasi film animasi dengan penyampaian cerita yang dipangkas langsung kepada intinya dan membuat animasi bahaya merokok versi realistik dengan unsur yang lebih menyeramkan agar penyampaian pesan bahaya merokok dapat lebih baik lagi.

\section{DAFTAR PUSTAKA}

Hamdan, S. R. (2015). Pengaruh Peringatan Bahaya Rokok Bergambar pada Intensi Berhenti Merokok. MIMBAR.

Indonesia, K. K. R. (2015). Inilah 4 Bahaya Merokok Bagi Kesehatan Tubuh. Retrieved from Kementrian Kesehatan Republik Indonesia website: http://www.depkes.go.id/development/site/depkes/index.php?cid=115112500015\&id=inilah-4-bahaya-merokok-bagi-kesehatan-tubuh.html

Indonesia, K. K. R. (2018). Hasil Utama Riskesdas 2018.

Kadar, J. T., Respati, T., \& Irasanti, S. N. (2017). Hubungan Tingkat Pengetahuan Bahaya Rokok dengan Perilaku Merokok Mahasiswa Laki-Laki di Fakultas Kedokteran. Bandung Meeting on Global Medicine \& Health (BaMGMH).

Nuswantari, A. (2014). Karakter Tanggung Jawab Dalam Film Animasi Petualangan Iko Di Dunia Maya Produksi PT.Studiokasatmata. HUMANIORA.

Organization, W. H. (2013). WHO report on the Global Tobacco Epidemic 2013 : enforcing bans on tobacco advertising, promotion and sponsorship. MPOWER.

Putri, N. W. E. (2016). Dunia Animasi. Denpasar: Fakultas Seni Rupa dan Desain Institut Seni Indonesia Denpasar.

Rhyandina, P. H., Tanudjaja, B. B., \& Kurniawan, D. (2017). Perancangan Iklan Layanan Masyarakat Bahaya Rokok Elektrik.

Saleh, R. Y. R., Arya, I. F. D., \& Afriandi, I. (2016). Film yang Efektif sebagai Media Promosi Kesehatan bagi Masyarakat. JSK.

Suryani, I. (2014). Peran Media Film Sebagai Media Kampanye Lingkungan Hidup Studi Kasus Pada Film Animasi 3D India "Delhi Safari." Jurnal IImu Komunikasi VOL 2 NO. 2. 